\title{
Environmental Disparity Index (EDI): The New Measurement to Assess Indonesia Environmental Conditions for Supporting Sustainable Development
}

\author{
Fitri Hariyanti $^{1,2,{ }^{*}}$, Bekti Indasari ${ }^{2}$, Almasdi Syahza ${ }^{1}$, Zulkarnain ${ }^{1}$, Nofrizal ${ }^{1}$ \\ ${ }^{1}$ Riau University, Pekanbaru, Riau, Indonesia 28293; ${ }^{2}$ BPS-Statistics of Riau Province, Pekanbaru, Riau, Indonesia 28131
}

Received: February 27, 2021; Revised: May 25, 2021; Accepted: June 22, 2021

\begin{abstract}
Countries in the world including Indonesia agreed to continue development by carrying out the concept of Sustainable Development Goals. Many environmental problems that occur in Indonesia and the world are the result of activities carried out by companies and by households. These cause a development system that is needed not only to pay attention to economic and social aspects but also to environmental aspects. To know about the success of development in the environmental field, a disparity analysis is needed to be done by measuring the gap in environmental conditions between provinces in Indonesia using the Environmental Disparity Index. This analysis was constructed using six dimensions based on the Framework for Development of Environment Statistics (FDES) 2013 which include environmental conditions and quality; natural resources and their use; residuals; extreme events and disasters, human settlements and environmental health; environmental protection, management, and engagement. The method used in this analysis was through the taxonomic method approach and factor analysis. The results of the analysis showed that there were significant disparities between provinces in Indonesia in the five dimensions of the environment. This was because each province had different component strengths depending on the character and potential of each region. West Papua was the province with the best environmental conditions, while the province with the worst environmental conditions was Jakarta. The impact of uneven development between Western Indonesia and Eastern Indonesia also affected the environmental conditions in the two regions. The environment of Eastern Indonesia was still better than Western Indonesia. The recommendations that need to be taken: reducing carbon dioxide emissions; enforcing environmental laws; harnessing natural resources for sustainable development; improving the lives of the poor; protection and environmental management on a serious and consistent basis by the government.
\end{abstract}

Keywords: Development, Disaster, Disparity, Environment, Residue, Resources

\section{Introduction}

Countries in the world, including Indonesia, have agreed to continue development by carrying out the concept of Sustainable Development Goals with the principle of meeting current needs without sacrificing the needs of future generations. To achieve comprehensive sustainability, it is necessary to integrate the three pillars of development, namely sustainability in the social, economic, and environmental aspects that integrate and strengthen one another (Purvis et al., 2019). For this reason, these three aspects must be integrated into the planning and implementation of development to achieve sustainable development which in addition to protecting the environment/ecology from destruction or quality degradation can also maintain social justice without sacrificing the needs of economic development (BAPPENAS, 2010).

Many environmental problems that occur in Indonesia and the world are a result of activities carried out by companies and by households. Besides, the lack of public awareness can further exacerbate environmental problems.
These cause a development system that is needed not only to pay attention to economic and social aspects but also to environmental aspects. In other words, a system that carries the concept of sustainable development is needed. One of the environmental problems in Indonesia is caused by the existence of large-scale industries. The research in Bangladesh shows that the lack of environmental responsiveness in several large-scale industries (include the tannery, pulp \& paper, fertilizer, textile and cement industries) has a major impact on human health and the environment. Besides, it also generates extraordinary socio-ecological problems and creates huge social costs (Hoque et al., 2018).

Another example, the dairy industry will produce milk waste. This waste is one of the significant wastes source of water pollution (Senousy \& Ellatif, 2020). Likewise, such fragile desert ecosystems are subjected to severe human activities (e.g. establishment of new urban settlements, road construction, construction of summer resorts along the coast, and significant uncontrolled grazing) contributed to land degradation, destruction of natural vegetation, loss of special resources, habitats and bidoversity (Salama et al., 2019). Another environmental issue is the management

\footnotetext{
* Corresponding author e-mail: fhariyanti@bps.go.id.
} 
of household waste. Management of waste sorting for households will help recover recyclable materials and can reduce the amount of waste in landfills (Maskey, 2018). There are many other environmental problems currently occurring in Indonesia.

To realize sustainable development, a development plan is needed that pays attention to the optimization of natural resources and their use. This as much as possible can prevent environmental damage and increase the carrying capacity of the environment. Besides, in order to evaluate the success of pro-environmental development both national and provincial levels, it is necessary to have an accurate measuring and reporting tool of an environmental parameter so that it can be compared, understood and replicated (Both et al., 2015). As well as being able to know the environmental conditions of the area accurately so that it can be used as a reference to increase environmental awareness. Therefore, it becomes a very important aspect.

Starting from the framework of the United NationFramework for the Development of Environment Statistics (UN-FDES), Indonesia and the Asian Development Bank (ADB) developed the Indonesian-Framework for the Development of Environment Statistics (IFDES) which include environmental conditions and quality; natural resources and their use; residuals; extreme events and disasters, human settlements and environmental health; environmental protection, management, and engagement (BPS, 2017). The six dimensions can be used as a measuring tool to know environmental conditions in Indonesia. In contrast to the new version of the Environmental Quality Index which combines the Air Pollutant Standard Index, Water Quality Index, Forest Cover Index, Biodiversity Index, Public Health Index, and Environmental Health Index as a basis for environmental quality assessment (Yuwono, 2012).

This study aims to determine environmental disparities in the provinces in Indonesia and also to know the Environmental Disparity Index (EDI) for each dimension (environmental conditions and quality; natural resources and their use; residuals; extreme events and disasters, human settlements and environmental health; environmental protection, management, and engagement) for each province in Indonesia. The benefits of this research study can be a reference for developing an environmental system to increase public awareness.

\section{Materials And Methods}

\subsection{Data Source}

This study is macro analysis at the provincial level, so an Environmental Disparity Index (EDI) will be obtained between provinces. In this paper, the source that will be used as a reference is national data. One limitation of the study is that several measuring variables that use different data years, but for each of the same measuring variables in different provinces use the same data year. In general, EDI is compiled using 2018 data, so the results described are close to those conditions of 2018.

\subsection{Conceptual Framework}

An analysis of environmental disparities was constructed using six dimensions, where each dimension consists of several measuring variables/indicators. The six dimensions used are Environmental Conditions and Quality; Natural Resources and their Use; Residuals; Extreme Events and Disasters, Human Settlements and Environmental Health; Environmental Protection, Management, and Engagement. Before variables are used to determine environmental disparity, variable selection is first carried out through the validity and reliability test and factor analysis. Based on this description, the research framework is described as follows:

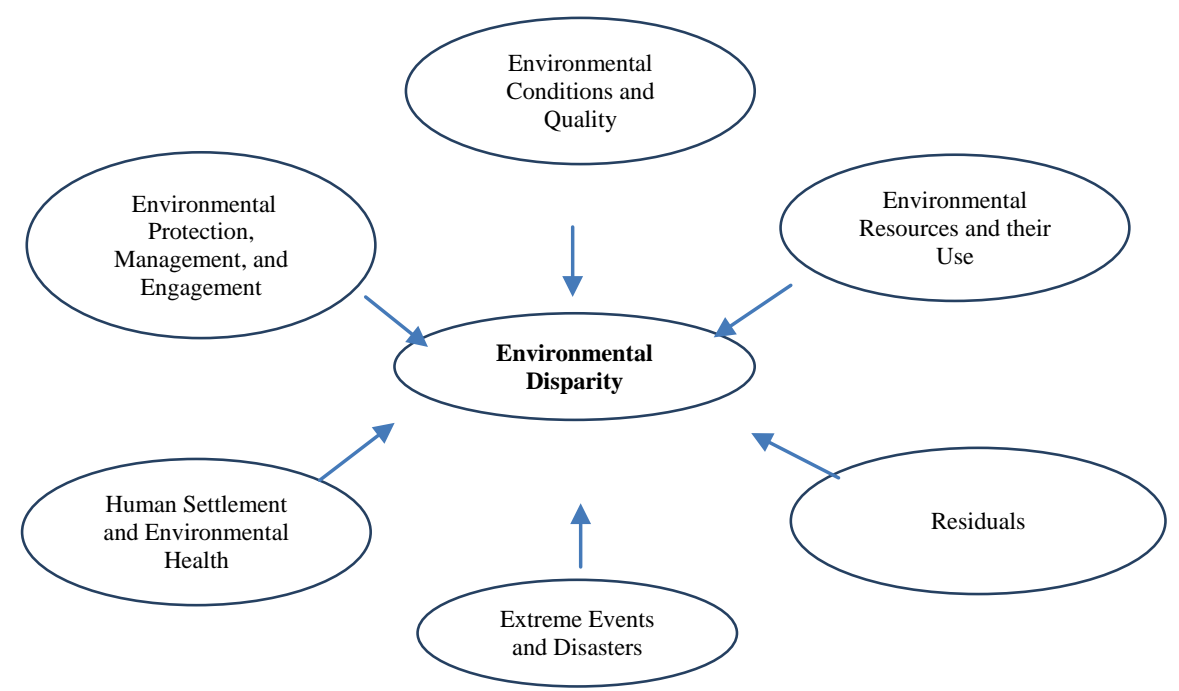

Figure 1. Conceptual Framework

\subsection{Variable Selection}

\subsubsection{Test Validity}

Validity is used to test the accuracy or correctness of the variables as a measuring tool for research. In other words, this test aims to assess whether the variables used are appropriate to measure the problem in a study. In this case, validity test aims to determine whether the variable/indicator used as a measure of environmental disparities is appropriate. To test the validity, the correlation coefficient is calculated between the candidate variables and the validator, using the Spearman Rank Correlation Coefficient. 
Table 1. Number of Valid Variables for Each Dimension

\begin{tabular}{ll}
\hline Dimension & Number of valid variables \\
\hline Environmental Conditions and Quality & - \\
Natural Resources and their Use & 12 \\
Residuals & 7 \\
Extreme Events and Disasters & 6 \\
Human Settlement and Environmental & 14 \\
Health & \\
Environmental Protection, & 6 \\
Management, and Engagement &
\end{tabular}

The variables used for the validity test are 74 variables. This analysis uses a $90 \%$ confidence level. Based on the results of the validity test, it is known that there are 29 invalid variables which cannot be used for further analysis.

\subsubsection{Test Reliability}

In addition to being valid for measuring disparity, some selected variables are also expected to make a large contribution to the reliability of the measure both jointly and individually. Reliability refers to how consistently a test measures a characteristic. The ideal size sought is a measure of high reliability, involving a few variables, and each variable has a significant contribution to the reliability of the size. The reliability level of a measure involving $k$ variables is calculated using the Cronbach's alpha formula (Carmines \& Zeller, 1979).

Table 2. The Results of Reliability Test

\begin{tabular}{ll}
\hline Dimension & Cronbach's Alpha \\
\hline Environmental Conditions and Quality & - \\
Natural Resources and their Use & 0.688 \\
Residuals & 0.900 \\
Extreme Events and Disasters & 0.800 \\
Human Settlement and Environmental Health & 0.722 \\
Environmental Protection, Management, and & 0.774 \\
Engagement & \\
\hline
\end{tabular}

Cronbach's Alpha is a measure of reliability that has values ranging from zero to one (Hair Jr et al., 2010). The minimum reliability level of Cronbach's Alpha is 0.60 (Ursachi et al., 2015). Based on the test results, the Cronbach Alpha value for each dimension is greater than
0.60 , which means that all dimensions in this study have met the reliable requirements.

\subsubsection{Composite Index Calculation}

This analysis was built using the taxonomic method approach which used to rank a group of countries, regions, or spatial units based on certain measures related to various socio-economic conditions of each country, region, or spatial unit. This method was originally proposed by Polish mathematicians under the leadership of Florek in 1952. In 1967, Hellwig proposed the method to UNESCO for international comparisons of economic and social development of countries in the world. Then in 1970 this method was used by Harbison, Maruhnik, and Resnik to make a study of the development of various countries (Arief, 2006).

The taxonomic method aims to determine a composite index (composite index) of various sizes, then based on the composite index a spatial unit ranking is made. Concerning the development input disparity analysis, the calculation of the composite index is based on several variables that have passed the validity and reliability tests.

\section{Results And Discussion}

In this study, variables that measured environmental disparity conditions were initially assessed based on concepts/definitions, theoretical studies, and data availability. The results of variable detection at this early stage obtained 74 variables selected as candidates to measure environmental disparity. Then all the candidate variables were further selected through validity, reliability and factor analysis. Based on these considerations, the study of environmental disparity was measured using 45 variables that passed the test and formed into five dimensions: Natural Resources and their Use; Residuals; Extreme Events and Disasters, Human Settlements and Environmental Health; Environmental Protection, Management, and Engagement. The results of the calculation of the Environmental Disparity Index (EDI) per dimension for each province in Indonesia were presented in Table 3.

Table 3. The Environmental Disparity Index (EDI) per Dimension for Each Province in Indonesia

\begin{tabular}{|c|c|c|c|c|c|c|}
\hline Province & $\begin{array}{l}\text { Natural Resources and } \\
\text { their Use }\end{array}$ & Residuals & $\begin{array}{l}\text { Extreme Events } \\
\text { and Disasters }\end{array}$ & $\begin{array}{l}\text { Human Settlement } \\
\text { and Environmental } \\
\text { Health }\end{array}$ & $\begin{array}{l}\text { Environmental } \\
\text { Protection, } \\
\text { Management and } \\
\text { Engagement }\end{array}$ & Total \\
\hline Aceh & 47.08 & 87.11 & 63.02 & 80.82 & 23.19 & 60.24 \\
\hline North Sumatera & 53.57 & 70.29 & 79.69 & 69.51 & 37.41 & 62.09 \\
\hline West Sumatera & 47.12 & 88.76 & 87.39 & 75.13 & 23.34 & 64.35 \\
\hline Riau & 33.20 & 86.18 & 87.81 & 79.30 & 29.91 & 63.28 \\
\hline Jambi & 43.40 & 86.00 & 93.35 & 77.51 & 31.69 & 66.39 \\
\hline South Sumatera & 51.14 & 80.73 & 89.05 & 77.30 & 38.42 & 67.33 \\
\hline Bengkulu & 42.07 & 95.15 & 97.70 & 74.59 & 21.46 & 66.19 \\
\hline Lampung & 63.07 & 82.44 & 91.47 & 74.08 & 28.15 & 67.84 \\
\hline Bangka Belitung Islands & 42.07 & 96.64 & 82.44 & 73.08 & 13.91 & 61.64 \\
\hline Riau Islands & 42.87 & 95.74 & 98.76 & 82.09 & 15.43 & 66.98 \\
\hline Jakarta & 42.61 & 46.65 & 89.05 & 44.07 & 20.31 & 48.54 \\
\hline West Java & 62.54 & 52.73 & 35.77 & 53.79 & 46.85 & 50.34 \\
\hline
\end{tabular}


Table 3. cont.

\begin{tabular}{|c|c|c|c|c|c|c|}
\hline Province & $\begin{array}{l}\text { Natural Resources } \\
\text { and their Use }\end{array}$ & Residuals & $\begin{array}{l}\text { Extreme Events } \\
\text { and Disasters }\end{array}$ & $\begin{array}{l}\text { Human Settlement } \\
\text { and Environmental Health }\end{array}$ & $\begin{array}{l}\text { Environmental } \\
\text { Protection, } \\
\text { Management and Engagement }\end{array}$ & Total \\
\hline Central Java & 72.27 & 47.14 & 33.50 & 65.83 & 77.01 & 59.15 \\
\hline Yogyakarta & 50.48 & 86.28 & 86.60 & 74.67 & 19.65 & 63.53 \\
\hline East Java & 69.50 & 31.66 & 42.28 & 59.21 & 61.55 & 52.84 \\
\hline Banten & 46.67 & 82.03 & 89.05 & 68.74 & 19.17 & 61.13 \\
\hline Bali & 45.36 & 83.66 & 87.41 & 82.87 & 22.04 & 64.27 \\
\hline $\begin{array}{l}\text { West Nusa } \\
\text { Tenggara }\end{array}$ & 46.58 & 87.33 & 75.01 & 81.22 & 21.29 & 62.29 \\
\hline $\begin{array}{l}\text { East Nusa } \\
\text { Tenggara }\end{array}$ & 46.98 & 90.45 & 78.43 & 82.36 & 21.93 & 64.03 \\
\hline West Kalimantan & 44.68 & 88.20 & 79.74 & 71.49 & 34.11 & 63.64 \\
\hline $\begin{array}{l}\text { Central } \\
\text { Kalimantan }\end{array}$ & 38.18 & 94.11 & 87.80 & 71.24 & 19.53 & 62.17 \\
\hline $\begin{array}{l}\text { South } \\
\text { Kalimantan }\end{array}$ & 39.00 & 88.26 & 88.38 & 74.83 & 45.51 & 67.20 \\
\hline East Kalimantan & 42.66 & 86.56 & 91.67 & 77.04 & 22.86 & 64.16 \\
\hline $\begin{array}{l}\text { North } \\
\text { Kalimantan }\end{array}$ & 38.32 & 100.00 & 99.71 & 82.19 & 12.20 & 66.48 \\
\hline North Sulawesi & 44.67 & 93.65 & 96.52 & 81.49 & 16.65 & 66.60 \\
\hline Central Sulawesi & 46.29 & 91.45 & 91.00 & 83.12 & 21.40 & 66.65 \\
\hline South Sulawesi & 51.13 & 75.42 & 83.23 & 81.97 & 30.16 & 64.38 \\
\hline $\begin{array}{l}\text { Southest } \\
\text { Sulawesi }\end{array}$ & 42.16 & 93.67 & 95.00 & 85.87 & 18.27 & 66.99 \\
\hline Gorontalo & 44.37 & 96.78 & 96.12 & 84.92 & 14.60 & 67.36 \\
\hline West Sulawesi & 49.63 & 98.52 & 98.60 & 80.83 & 17.90 & 69.10 \\
\hline Maluku & 44.47 & 97.55 & 98.67 & 86.00 & 21.78 & 69.69 \\
\hline North Maluku & 39.27 & 99.01 & 96.94 & 84.05 & 14.41 & 66.74 \\
\hline West Papua & 48.80 & 99.44 & 98.61 & 88.36 & 15.53 & 70.15 \\
\hline Papua & 29.13 & 95.75 & 91.46 & 80.83 & 20.99 & 63.63 \\
\hline
\end{tabular}

3.1. Environmental Disparity per Dimension

\subsubsection{Natural Resources and their Use}

Indonesia was located on the equator and had a tropical climate. This country also had a lot of potential natural resources including soil resources at the bottom layer (minerals and energy), land resources, biological resources, and water resources. These could be used as a driving force for development. These natural resources could be classified as renewable and non-renewable. Natural resources were important capital in the development process and were used as input in the process of production and consumption of human activities such as the provision of housing, food, health, transportation, infrastructure, and so on.

As a rich country in natural resources, it was very important to know the extent to which these natural resources could play a role in the development process both at the national level and in each province. Therefore, information regarding its availability and use was very important for policymakers to make decisions and to maintain their sustainability. The difference in potential natural resources and their use in each province was what causes disparities in the environment in the dimensions of natural resources and their use.

By using the taxonomic method, the value of the Environmental Disparity Index (EDI) in dimensions of natural resources and their use was obtained. EDI value of 34 provinces are divided into five radii, where each radius represents the level of environmental disparity between provinces. Provinces that were in the same radius can be known they have gaps in environmental conditions that were not too large. Otherwise, if the two provinces were in different radius then it could be known they had a greater gap in environmental conditions.

Based on the results of the EDI analysis, it was known that the disparity measure for this dimension was in the range of 0.00 to 0.50 which was divided into 5 radii. Central Java, East Java, Lampung, and West Java were in the first radius with a range of $0.00-0.10$. The first radius indicated the highest rank of this dimension. Meanwhile, the province with the lowest rank in the dimension of natural resource and its use was Papua. Papua is in the fifth radius with a range of $0.40-0.50$. Besides, the development measured for this dimension in 28 provinces was spread over a radius range of $0.10-0.50$. 


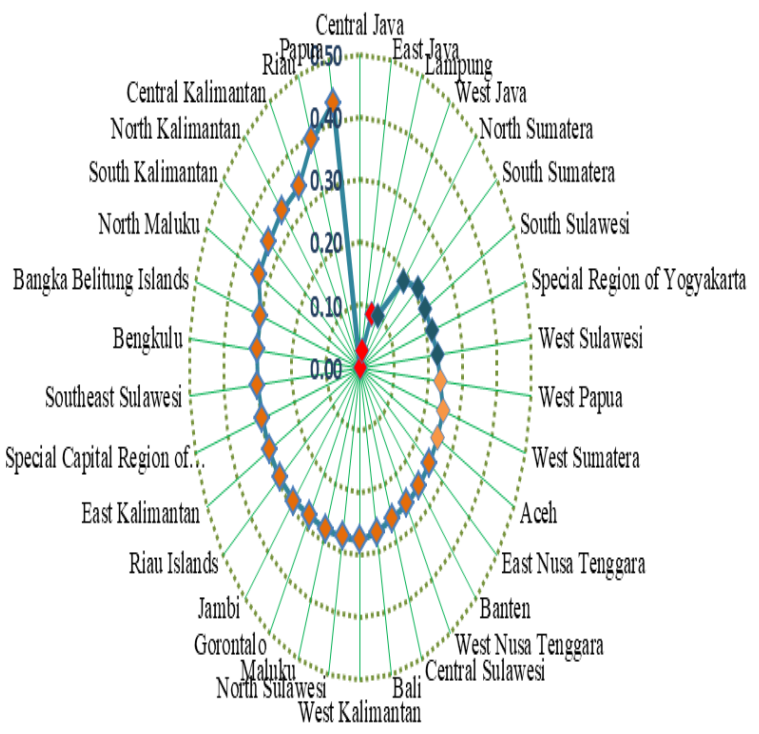

Figure 2. The Measure of Environmental Conditions and EDI Ranking Based on the Dimension of Natural Resource and Its Use in 2018

Figure 2 explained that Papua and Riau were in the lowest rank for the measure of environmental conditions based on the dimension of natural resource and its use. For Riau, this indicated high natural resource ownership and extensive forest ownership, but there was a lot of deforestation and fire on these forest lands. Papua, in particular, had a very high forest area, but the use of agricultural food crops was still very low. The four provinces that ranked the best in terms of potential environmental conditions were Central Java, East Java, Lampung, and West Java, respectively. These four provinces were seen as the top provinces in terms of the potential for land use for food crop agriculture coupled with the absence of deforestation activities on forest land.

\subsubsection{Residuals}

Various human activities could generate residues, for example from simple things such as breathing, eating, cooking, using vehicles, and other activities. All of these activities generated residues that were released through the production and consumption processes into the environment, either directly released or collected, processed before disposal, recycled or reused. The resulting residues could be harmful or harmless. Harmful residues could increase greenhouse gases which currently became one of the world's discussion topics.

Greenhouse Gases were gases in the atmosphere that caused global warming and climate change. In Presidential Regulation No. 71 of 2011 concerning the National Greenhouse Gas Inventory, there were several types that classified as GHG, such as carbon dioxide $\left(\mathrm{CO}_{2}\right)$, methane $\left(\mathrm{CH}_{4}\right)$, and nitrogen oxides $\left(\mathrm{N}_{2} \mathrm{O}\right)$, sulfur hexafluoride $\left(\mathrm{SF}_{6}\right)$, perfluorocarbons (PFCS), and hydrofluorocarbons (HFCS). $\mathrm{CO}_{2}, \mathrm{CH}_{4}$, and $\mathrm{N}_{2} \mathrm{O}$ had important roles as major contributors to climate change because they were included in long-lived greenhouse gases (WMO, 2014).

In this section, the gap between provinces that occured in the residual dimension would be measured using 7 indicators that had passed the variable selection. Before being used to calculate the composite disparity index, there were 10 variables based on similarities in measuring the environmental conditions of the residual dimensions. Furthermore, EDI and ranking of each province were calculated with the taxonomic method, the results of which were shown in Figure 3.

From Figure 3, it was known that by using the ideal value as a reference, the environmental disparity measure of residual dimensions could be grouped in 5 radii. About this grouping, there were 15 provinces located in the first radius with the best rank being North Kalimantan. Meanwhile, there was one province located in radius 5 and the lowest is East Java. The results of the provincial grouping in the residual dimensions indicated that provinces which were in the same radius tended to have the potential to produce residues that are almost the same when compared to provinces located in different radius. So the gap between provinces which are within the same radius is relatively low.

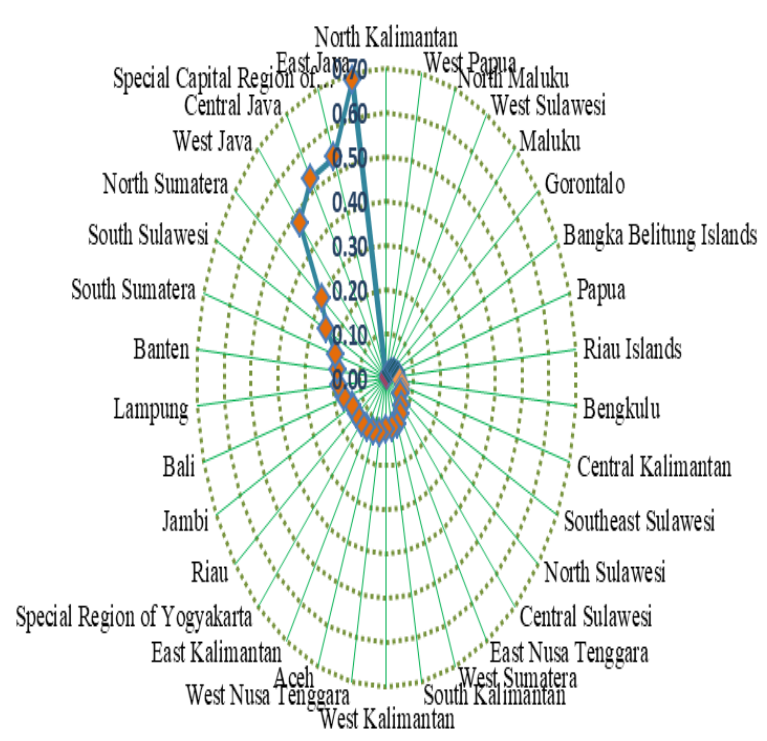

Figure 3. The Measure of Environmental Conditions And EDI Ranking Based on the Dimension of Residue in 2018

East Java and Jakarta were in the last radius which showed that two provinces had the greatest potential in producing residuals. It happened because both were big provinces in Indonesia that produced a lot of emissions from households, gasoline, diesel, motorized vehicles. Especially for East Java coupled with $\mathrm{CH}_{4}$ emissions from livestock. Meanwhile, North Kalimantan as a newly formed province had the lowest potential to produce residues. The residual gap between East Java and North Kalimantan was estimated to be proportional to the environmental disparity measure difference of the two provinces.

\subsubsection{Extreme Events and Disasters}

One of the factors that could disrupt environmental balance was extreme events and natural disasters. Coupled with destructive human behavior and activities could increase the frequency and severity that occurred; for example illegal logging could cause floods, landslides, and drought. Disasters could cause a lot of loss both in terms of casualties and material as well as infrastructure damage because natural disasters usually came suddenly or through a gradual process (Fillah et al., 2016).

Preparedness and alertness in dealing with the threat of disaster are vital for a country. For this reason, precise and 
accurate data or information were important to increase awareness and anticipation so that the impacts resulting from disasters could be reduced. As a Non-Departmental Government Institution, the National Disaster Management Agency had the task of assisting the President in carrying out disaster management. From this institution, the types of natural disasters can be identified and mapped based on the number and type that frequently occur.

In this section, disparity of extreme events and disasters will be explained through 6 measuring variables as mentioned in Table 1. From Figure 4, it could be explained that the disparity measure for this dimension could be grouped into 5 radii, where each radius used an interval of 0.15 . The results showed that provinces within the same tended to have almost the same potential for extreme events and natural disasters, so the gap between environmental conditions for this dimension tended to be the same. Central Java was the province with the most landslides and floods, and the number of victims and physical damage due to disasters was also the highest compared to other provinces. This was what caused Central Java to be an area with the highest potential for extreme events and disasters.

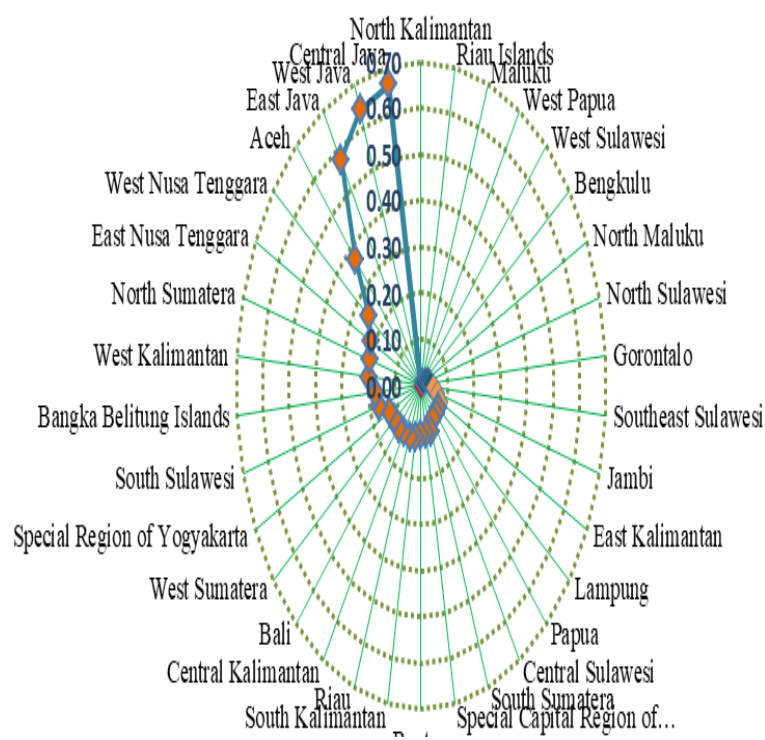

Figure 4. The Measure of Environmental Conditions and EDI Ranking Based on the Dimension of Extreme Events and Disasters in 2018.

\subsubsection{Human Settlement and Environmental Health}

The Framework for Development of Environment Statistics (FDES) 2013 explained that residential settlements could differ from small rural areas and urban or metropolitan cities. Besides, the addition of the population also presented its challenges to changing environmental conditions. Activities that were carried out continuously in settlements could cause environmental changes that could damage existing resources. The ability of the environment to cope with impacts caused by residential activities could affect the health of residents and the surrounding environment. Various efforts could be made to improve the health of settlements and the environment by providing waste disposal, providing infrastructure for water supply and sanitation, planning land used wisely, providing clean and safe transportation, ecosystem health, etc.

Based on the report of the United Nations (UN) by the titled "Urban and Rural Areas 2014," it was mentioned that the world population would increase to 8.42 billion people in 2030 from the number of 7.24 billion people in 2014 . The number would continue to grow to 9.55 billion in 2050. Based on estimates, more world population lived in urban areas than in rural areas. There was 53.6 percent in 2014 to 60.0 percent in 2030 and 66.4 percent in 2050. The same trend of population development also happened in Indonesia. The results of population projections made by Statistics Indonesia (BPS), the population of Indonesia in 2025 would rise to 284.83 million from 238.52 million in 2010. This number would continue to increase to 305.65 million by 2035. Based on projections, more Indonesia's population would live in urban areas than in rural areas at 63.4 percent in 2030 and 66.6 percent in 2035 (BPS, 2017).

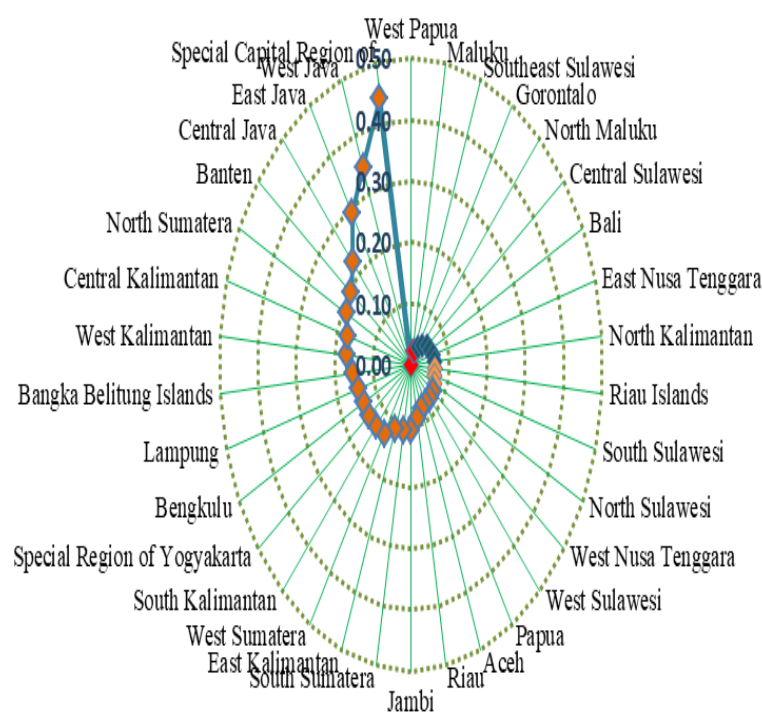

Figure 5. The Measure of Environmental Conditions and EDI Ranking Based on the Dimension Of Settlement and Environmental Health in 2018. 
This increase in population would affect the availability of adequate basic needs in each province. Access to basic needs such as access to drinking water, sanitation, garbage/ waste disposal, and access to energy sources could have a positive impact on health, well-being, and environmental quality. So the existence of this access is important to determine the policy of a region.

Furthermore, by observing the EDI ranking for the dimensions of settlement and environmental health, it could be seen that 3 provinces ranking as the best EDI in a row are West Papua, Maluku, and Southeast Sulawesi, while the 3 provinces that had lowest rank, respectively are Jakarta, West Java, and East Java. If explored further, the superiority of West Papua in this dimension was due to the relatively low number and population density. Likewise, the percentage of villages according to water, air, and soil pollution is also relatively low. Meanwhile, the disparity in dimensions of settlements and environmental health in Jakarta was due to a large number of population and high population density. Furthermore, the percentage of households based on improved drinking water sources and access to proper sanitation services was also very low, coupled with the very high percentage of regions according to water pollution and air pollution.

\subsubsection{Environmental Protection, Management and Engagement}

The protection and management of natural resources is an activity that aimed to preserve and maintain the stock of natural resources. Natural resource management activities included the management of energy and mineral resources, wood resources, aquatic resources, other biological resources, water resources, research and development activities for resource management, and other resource management activities (BPS, 2017).

In Indonesia, the Ministry of Environment and Forestry had the task of organizing government affairs in the field of environment and forestry to assist the President in organizing state government. One of the functions established by the Ministry of Environment and Forestry was to implement policies in the field of sustaining the establishment of forest areas and the environment in a sustainable manner, managing conservation of natural resources and their ecosystems, enhancing the carrying capacity of watersheds and protection forests, managing sustainable production forests, increasing power primary industry competitiveness of forest products, improvement of the quality of environmental functions, control of pollution and environmental damage, control of climate change, control of forest and land fires, social forestry and environmental partnerships, as well as reduction of disturbances, threats, and violations of laws in the field of environment and forestry (BPS, 2017).

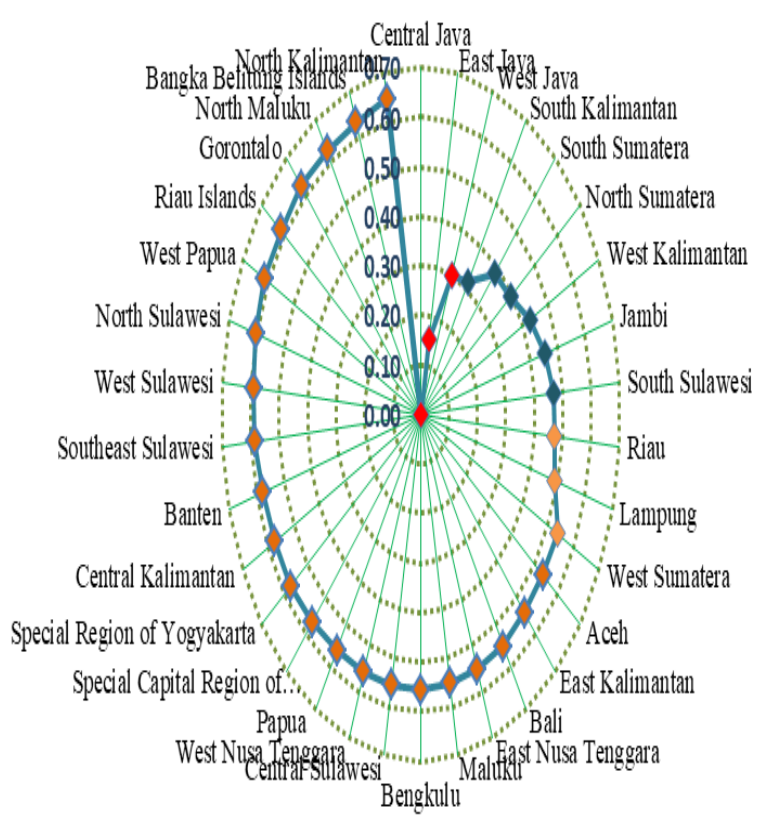

Figure 6. The Measure of Environmental Conditions and EDI Ranking Basedon the Dimension of Environmental Protection, Management, and Engagement in 2018

The best province for this dimension was Central Java. If explored further, then the superiority of Central Java in this dimension was due to the many environmental institutions, a large number of forestry extension workers both civil servants, private and non-governmental organizations. As well as supported by the number of schools that received an appreciation for successfully carrying out the environmental care and culture movement (i.e. Adiwiyata). Meanwhile, North Kalimantan is the province with the lowest rank in Indonesia. This is because it has the fewest environmental institutions and the number of forestry extension workers (both civil servants, private and non-governmental organizations).

\subsection{Environmental Disparity for All Dimensions}

The overall dimensions referred were a combination of the dimensions used to calculate the Environmental Disparity Index (EDI), there were Natural Resources and their Use; Residuals; Extreme Events and Disasters, Human Settlements and Environmental Health; Environmental Protection, Management, and Engagement. This measure seen from the composite index was recalculated with each dimension as input. Each province had different dimension strengths. For example, Central Java had a superior dimension on natural resources and their use as well as participation, management, and environmental protection, while West Papua had a superior dimension on residue as well as settlements and environmental health. These strengths complement each other to describe environmental conditions. After weighting for all dimensions, the top 3 best provinces were West Papua (1), Maluku (2), and West Sulawesi (3). Whereas the 3 provinces with the lowest index were East Java (32), West Java (33), and Jakarta (34). 


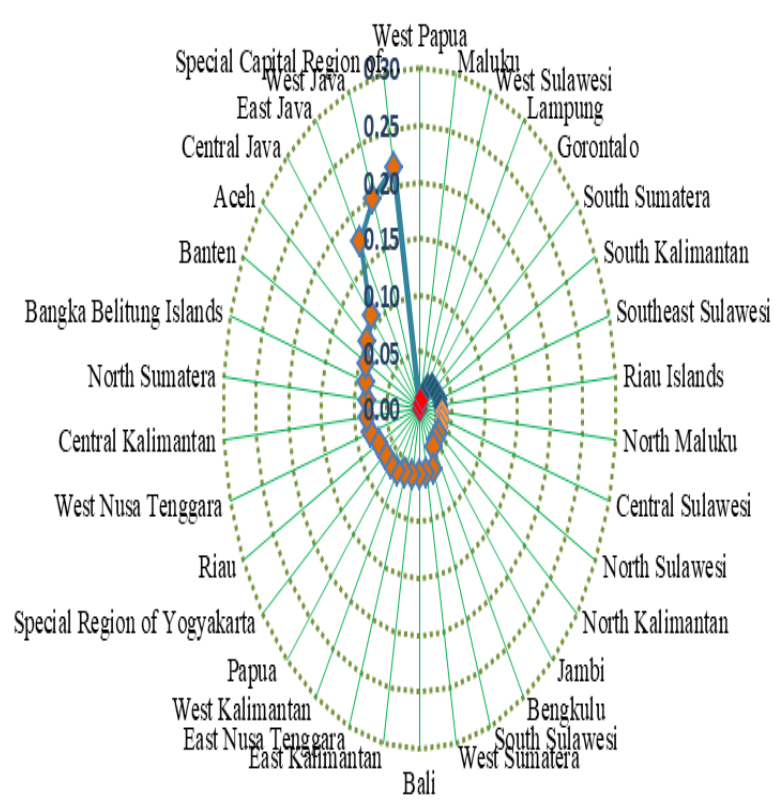

Figure 7. The Measure of Environmental Conditions and EDI Ranking for All Dimensions in 2018

Based on the previous analysis, West Papua had the strength that is the basis for its environmental conditions, such as the low residue generated, fairly good settlement and health conditions, and the occurrence of extreme events and disasters that were not so high. Meanwhile, the dimension of natural resources and their use were relatively low. This was because despite having a high area of land and forest land, the use was still considered low. Jakarta was the province with the lowest IDE value. This was because Jakarta had weaknesses in almost all dimensions, although in some dimensions it was not the lowest. The fundamental flaw in Jakarta is being the largest residue-producing province. Likewise, for the dimensions of settlement and environmental health, Jakarta has the lowest score. This is because it has the highest population density, which causes the lack of access to basic facilities such as drinking water and sanitation services.

\subsection{Environmental Disparity by Region}

The terms of Western Indonesia and Eastern Indonesia began since the formation of the State Policy Guidelines in 1993, and it turned out that until now the term regional division was still often used. The Western Indonesia consisted of Java, Sumatra, Kalimantan, and Bali. Whereas Eastern Indonesia consisted of Sulawesi, Maluku, Papua, West Nusa Tenggara, and East Nusa Tenggara. There was a difference between Western Indonesia and Eastern Indonesia in terms of development. When viewed further, the population of Western Indonesia was much greater so that the real economic activities that were in line with market mechanisms were also higher in this region. Eastern Indonesia had a larger area and had a wealth of natural resources that was very much so it was very ironic if Eastern Indonesia must continue to face the backward development and low welfare of its people.

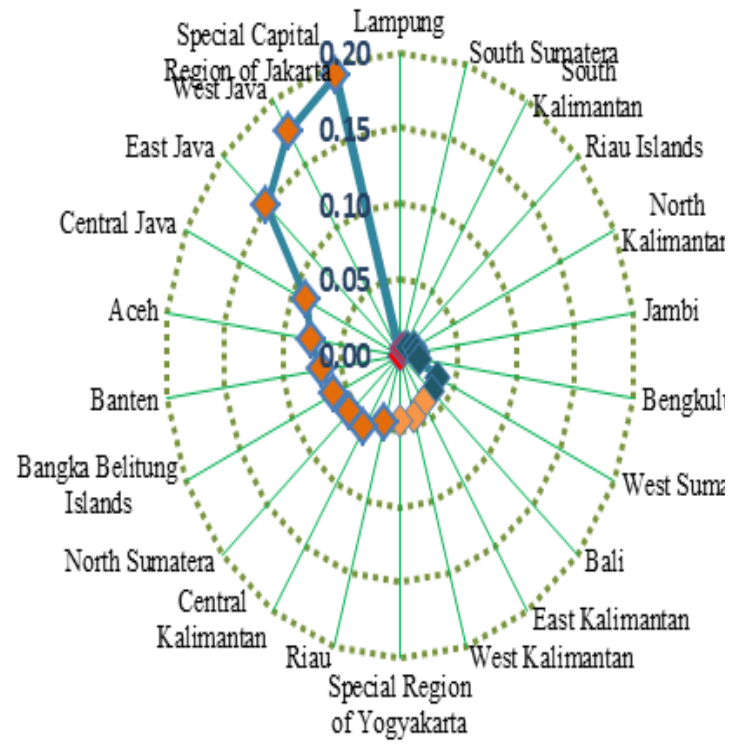

Figure 8. Western Indonesia

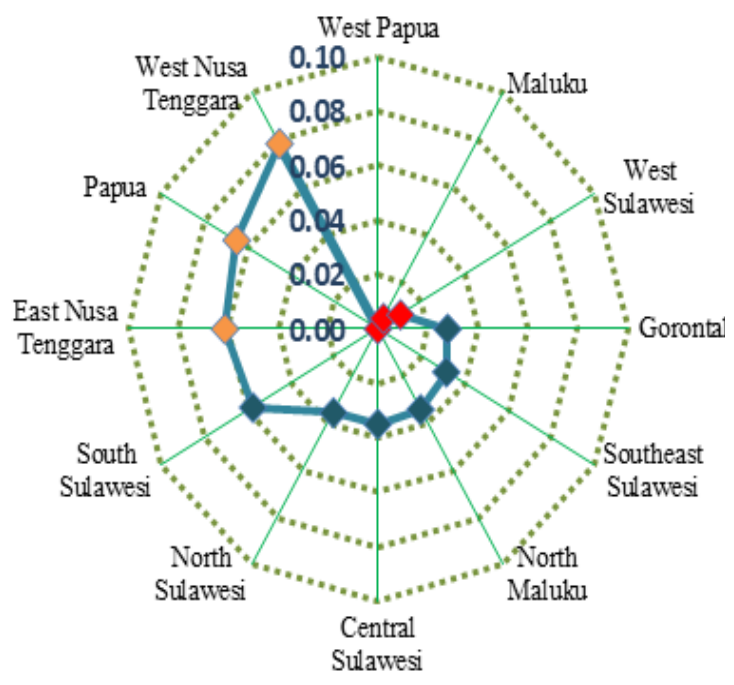

Figure 9. Eastern Indonesia

Based on Figure 8 and Figure 9 it could be seen that for Western Indonesia, Lampung and South Sumatra were the two provinces with the best Environmental Disparity Index (EDI), while the provinces with the lowest EDI were Jakarta and West Java. For the eastern part of Indonesia, West Papua was the province with the highest EDI, while the West Nusa Tenggara was province with the lowest EDI for this region.

The impact of uneven development between Western Indonesia and Eastern Indonesia also affected the environmental conditions in the two regions. The environment of Eastern Indonesia was still better than Western Indonesia because the residuals generated from community activities and economic activities were still low, the number of extreme events and natural disasters was also lower, and also the condition of settlements and environmental health was better. To overcome the gap between Western Indonesia and Eastern Indonesia, the government paid attention and made a priority for Eastern Indonesia's development. Various efforts were made to increase development in Eastern Indonesia so that it would not be left behind. 


\section{Conclusion}

Differences in potential human resources and activities that occur in each province in Indonesia cause environmental disparities. To accurately know the local environmental conditions and that can be used as a reference to increase public awareness, a measuring tool is needed, namely the Environmental Disparity Index (EDI). The Environmental Disparity Index is divided into five dimensions: Natural Resources and their Use; Residuals; Extreme Events and Disasters, Human Settlements and Environmental Health; Environmental Protection, Management, and Engagement.

In all dimensions, West Papua has the strengths that are the basis for its environmental conditions, namely the low residue generated, the relatively good settlement and health conditions, and the occurrence of extreme events and natural disasters that are not so high. Meanwhile, the dimensions of natural resources and their use in this province are relatively low. This is because despite having a high area of land and forest land, the use side is still considered low, while Jakarta is a province with the lowest EDI value. This is because Jakarta is the largest producer of residues compared to other provinces. Likewise, for the dimensions of settlement and health, this province has the lowest value because the number and level of population density are the highest, which causes access to basic facilities to be as low as access to drinking water sources and proper sanitation services.

If differentiated by region, for the Western Indonesia, Lampung and South Sumatra are the two provinces with the best Environmental Disparity Index (EDI), while the provinces with the lowest EDI are Jakarta and West Java. For Eastern Indonesia, West Papua is the province with the highest EDI, while the West Nusa Tenggara is the province with the lowest EDI for this region.

Recommendations that can be given from the results of the analysis are the reduction of residues such as carbon dioxide emissions from burning fossil fuels and switching to environmentally friendly energy sources; enforcing rules and sanctions in violation of environmental laws; sustainable use of natural resources; improving the standard of living of the poor so that they can obtain a better social, economic and environmental life. The seriousness of the government is important in the management and protection of the environment both through increasing the government budget and the active role in protecting the environment.

\section{Reference}

Arief S. 2006. Metodologi Penelitian Ekonomi (Metode Taksonomik). UI-Press, Depok.

BAPPENAS. 2010. Laporan Pencapaian Tujuan Pembangunan Milenium Indonesia. Bappenas, Jakarta.

Both AJ, Benjamin L, Franklin J, Holroyd G, Incoll LD, Lefsurd MG and Pitkin G. 2015. Guidelines for measuring and reporting environmental parameters for experiments in greenhouses. Plant Methods., 11: 43.

BPS. 2017. Statistik Lingkungan Hidup Indonesia 2016. BPS, Jakarta.

Carmines EG and Zeller RA. 1979. Reliability and Validity Assessment. Sage Publications, California.

Fillah AS, Ishartono I and Fedryansyah M. 2016. Program penanggulangan bencana oleh Disaster Management Center (DMC) Dompet Dhuafa. Prosiding Penelitian \& Pengabdian Kepada Masyarakat. Universitas Padjadjaran. Sumedang, Indonesia.

Hair Jr JF, Black WC, Babin BJ and Anderson RE. 2010. Multivariate Data Analysis, seventh ed. Pearson, London.

Hoque ASMM, Siddiqui BA, Awang ZB and Baharu SMAT. 2018. Exploratory factor analysis of entrepreneurial orientation in the context of Bangladeshi Small and Medium Enterprises (SMEs). Eur J Manage Mark Stud., 3(2): 81-94.

Maskey B. 2018. Determinants of household waste segregation in Gorkha Municipality, Nepal. J Sustainable Dev., 11(1): 1-12.

Purvis B, Mao Y and Robinson D. 2019. Three pillars of sustainability: In search of conceptual origins. Sustainability Sci., 14(3): 681-695.

Salama FM, El-Ghani MMA, El-Tayeh NA, Amro AM, Gaafar AA and El-Galil AAEA. 2019. Assessing the role of environmental gradients on the phytodiversity in Kharga Oasis of Western Desert, Egypt. Jordan J Biol Sci., 12(4): 421-434.

Senousy HH and Ellatif SA. 2020. Mixotrophic cultivation of Coccomyxa subellipsoidea microalga on industrial dairy wastewater as an innovative method for biodiesel lipids production. Jordan J Biol Sci., 13(1): 47-54.

Ursachi G, Horodnic IA and Zait A. 2015. How reliable are measurement scales? External factors with indirect influence on reliability estimators. Procedia Econ Finance., 20: 679-686.

WMO. 2014. El Nino/Shouthern Oscillation. Chairperson, Geneva.

Yuwono AS. 2012. Indeks Kualitas Lingkungan Hidup (IKLH) versi baru sebagai dasar implementasi analisis risiko lingkungan. Prosiding Seminar Nasional. Institut Pertanian Bogor. Bogor, Indonesia. 